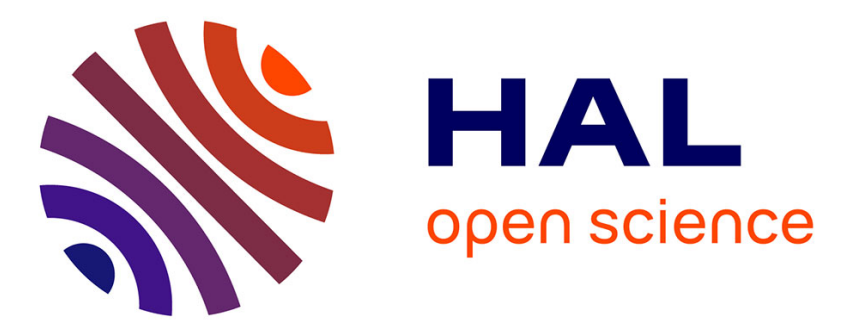

\title{
Exposure to thymol decreased phototactic behaviour in the honeybee (Apis mellifera) in laboratory conditions
}

Maelys Bergougnoux, Michel Treilhou, Catherine Armengaud

\section{To cite this version:}

Maelys Bergougnoux, Michel Treilhou, Catherine Armengaud. Exposure to thymol decreased phototactic behaviour in the honeybee (Apis mellifera) in laboratory conditions. Apidologie, 2012, 44 (1), pp.82-89. 10.1007/s13592-012-0158-5 . hal-01201274

\section{HAL Id: hal-01201274 \\ https://hal.science/hal-01201274}

Submitted on 17 Sep 2015

HAL is a multi-disciplinary open access archive for the deposit and dissemination of scientific research documents, whether they are published or not. The documents may come from teaching and research institutions in France or abroad, or from public or private research centers.
L'archive ouverte pluridisciplinaire HAL, est destinée au dépôt et à la diffusion de documents scientifiques de niveau recherche, publiés ou non, émanant des établissements d'enseignement et de recherche français ou étrangers, des laboratoires publics ou privés. 


\title{
Exposure to thymol decreased phototactic behaviour in the honeybee (Apis mellifera) in laboratory conditions
}

\author{
Maelys Bergougnoux ${ }^{1}$, Michel Treilhou ${ }^{2}$, Catherine Armengaud ${ }^{1}$ \\ ${ }^{1}$ Centre de Recherches sur la Cognition Animale, Université Paul Sabatier Toulouse III-CNRS UMR 5169, 118 \\ Route de Narbonne, 31062 Toulouse Cedex 4, France \\ ${ }^{2}$ EA4357, Centre Universitaire Jean-François Champollion, Place de Verdun, 81012 Albi Cedex 09, France
}

Received 18 January 2012 - Revised 16 April 2012 - Accepted 6 July 2012

\begin{abstract}
The effects of the terpenoid thymol were evaluated on the phototactic behaviour of the adult honeybee (Apis mellifera) 1 and $24 \mathrm{~h}$ after a topical application. The behaviour was quantified under different light intensities by measuring the time spent in the light source area and in areas opposite the source. Stimuli of $200 \mathrm{~lx}$ induced positive phototaxis of the bees. Thymol administered at $1 \mathrm{ng} / \mathrm{bee}$ had no effect on the phototaxic behaviour while bees that had received 10 or $100 \mathrm{ng}$ thymol $1 \mathrm{~h}$ before the test were less attracted by the 200-lx stimulus. The effect of thymol increased when the phototaxic behaviour was tested $24 \mathrm{~h}$ after the topical application. However, with a light intensity of $400 \mathrm{~lx}$ the dose $10 \mathrm{ng} / \mathrm{bee}$ was ineffective and for $600 \mathrm{~lx}$ the phototaxic behaviour of the bees was not modified by the exposure to thymol.
\end{abstract}

thymol / honeybee / phototaxis / laboratory bioassay

\section{INTRODUCTION}

The search for alternatives to pesticide use, antibiotic treatment of diseased beehives and the fight against Varroa destructor is linked to the preservation of the environment but also to the problem of resistance to some molecules. An interest in essential oils has grown as these products could represent a natural alternative to the use of synthetic substances (Waliwitiya et al. 2009; Nerio et al. 2010). In recent years, substances from plants have been tested for their repellent action against parasites, their insecticidal activity (Umpierrez et al. 2011) and also for reducing Nosema infection in the bee (Costa et al. 2010). The repellent and insecticidal activities of essential oils are largely due to the presence of monoterpenes and phenolic compounds in particular thymol (Pandey et al. 2009). Thymol is

Corresponding author: C. Armengaud, catherine.armengaud@univ-tlse3.fr Manuscript editor: Bernd Grünewald the main phenolic compound derived from Thymus vulgaris that has proven to be effective in reducing the development and survival of adult mosquitoes (Pavela et al. 2009; Tabanca et al. 2010) and cockroaches (Phillips et al. 2010). In addition to the insecticidal properties, thymol may also have acaricidal properties against the varroa mite (Varroa destructor) (Imdorf et al. 1995). This ectoparasite of the honeybee has developed resistance to synthetic drugs (Milani 1999), and this has led beekeepers to move into new molecules such as thymol. Thymol is used in the form of crystals or commercial formulations (Thymovar ${ }^{\circledR}$, Apiguard ${ }^{\circledR}$ and ApilifeVar ${ }^{\circledR}$ ). Thus, at the end of summer when the hives are treated against the varroa mite bees may be exposed to thymol. In an early study conducted in the laboratory, it was reported that a stream of air containing thymol in doses between 5 and $15 \mu \mathrm{g} / \mathrm{L}$ could kill $100 \%$ of the mites exposed without affecting bee survival (Imdorf et al. 1995).

However, residues were found in honey and wax and a negative effect of thymol-based treat- 
ments on the colony was reported (Floris et al. 2004). Recently, Mondet et al. (2011) observed in laboratory assays that bee behaviour could be modified by the gel formulation Apiguard ${ }^{\circledR}$. Foragers were repelled by Apiguard ${ }^{\circledR}$ and presented energetic fanning behaviour.

Given the cellular targets of thymol, in addition to its repellent effects, other sublethal effects of this molecule can exist. In the mollusc Lymnae acuminata, thymol reduced the levels of serotonin (Singh et al. 1999). Serotonin was found to be involved in the phototactic behaviour of bees (Thamm et al. 2010). Moreover, insect tyramine and octopamine receptors were discussed as molecular targets of essential oil components including thymol (Blenau et al. 2011). It was reported that octopamine influences period gene expression and locomotor behaviour in the honeybee (Bloch and Meshi 2007). These authors had suggested that the light perception of bees could be modified by octopamine treatment (Bloch and Meshi 2007). In Drosophila, it was shown that thymol is an inhibitor of transient receptor potential-like (TRPL) channels (Parnas et al. 2009). Visual perception of Drosophila involves TRPL channels (Cosens and Manning 1969; Landry et al. 2007; Delgado and Bacigalupo 2009) and TRPL expression in Drosophila melanogaster peaks at the end of the day (Wijnen et al. 2006). Thus, it appeared relevant to study the visual function of the bees when they were exposed to thymol. To address this question we investigated the phototactic response of bees to light sources of different intensities after a topical application of thymol.

\section{MATERIAL AND METHODS}

\subsection{Bees}

The colony and the hive had not received any treatment specially miticide treatment for 1 year before the beginning of the experiment. Adult bees were collected in the morning from an indoor and an outdoor hive from October to December. During this period, bees continued to leave the hive. The bees were transported to the lab in glass vials and immobilized by cooling the vials to $4{ }^{\circ} \mathrm{C}$ in ice. The animals were transferred individually in a $5-\mathrm{mL}$ syringe with six ventilation holes. Because responsiveness to visual stimuli is correlated with gustatory responsiveness i.e. bees displaying a high gustatory responsiveness are also sensitive to light (Erber et al. 2006); motivation of bees to sucrose was checked before the phototaxis evaluation. Bees were fed with $10 \mu \mathrm{L}$ of a $30 \%$ sucrose solution, then starved for $3 \mathrm{~h}$ before the test. The syringes were used for retention during feeding and application of thymol on the bee's thorax. They were also used for transporting bees to and from the open-field and for contention during the resting periods at $33{ }^{\circ} \mathrm{C}$ after tests that did not exceed $48 \mathrm{~h}$. Mortality was monitored over the $48 \mathrm{~h}$ following treatment.

\subsection{Thymol exposure}

The $\mathrm{LD}_{50}$ of thyme essential oil was $8 \mathrm{mg} / \mathrm{bee}$ (Albo et al. 2003). Thymol has been shown not to be toxic at the doses tested in the present experiments and the doses tested could be considered as sublethal. In addition, in the present experimental condition, no increase in the longevity of thymol-treated bees could be expected for a short period of $48 \mathrm{~h}$ (Costa et al. 2010). One hour before the test, bees received a $1-\mu \mathrm{L}$ drop of thymol solution on the thorax. Thymol (thymol minimum $99.5 \%$, Sigma) was first dissolved in acetone then diluted in water. Acetone at $0.1 \%$ was present uniformly in all the solutions used for the topical application. Four experimental groups were conducted in parallel: control group $(0.1 \%$ acetone $)$ and thymol groups composed of bees treated at 1,10 and $100 \mathrm{ng} / \mathrm{bee}$. Each group was composed of six bees. Experiments conducted with $200 \mathrm{~lx}$ were repeated three times (18 bees in total for each group) and two separate experiments were performed with 400 and $600 \mathrm{~lx}$ (12 bees in total for each group).

\subsection{Measurement of phototaxis behaviour}

The experiments were conducted at the individual level on bees and allowed precise control of experimental parameters: quantity of thymol delivered to each bee, physiological state and duration of exposure. The walking behaviour of each bee was 
measured 1 and $24 \mathrm{~h}$ after thymol application. In their natural environment, honeybees are positively gravitaxic and positively phototaxic when they walk along the frames to the exit of the hive. The light intensity at the level of the bottom board was $30 \mathrm{~lx}$ inside the hive and 1,200 lx outside the hive. The phototaxis behaviour was analysed in an open field designed to investigate locomotor activity (Lambin et al. 2001). So we modified the protocol previously used in the design to reach the conditions met by bees in a hive. The arena (length, $30 \mathrm{~cm}$; height, $30 \mathrm{~cm}$ and depth, $4 \mathrm{~cm}$ ) was standing vertical. The PVC back of the area was divided into six horizontal levels of $5 \mathrm{~cm}$ (level 1: bottom of the device, level 6: top of the device) with each level divided into squares of $5 \times$ $5 \mathrm{~cm}$. In the present protocol each bee was introduced in the top left corner of the device. It was illuminated from its right bottom corner where the bee could find the exit (Figure 1a). The light stimuli were produced by two quartz halogen lamps $(150 \mathrm{~W})$ with intensity variation. Light intensities of 200, 400 and $600 \mathrm{~lx}$ were measured directly in square $1.12 \mathrm{~cm}$ from the source with a lux meter. The source was $35 \mathrm{~cm}$ from the open-field entrance. A computer was placed on the right of the light source on the same table. The observations took place in a cabin with a black curtain kept in the dark. Data were collected for $3 \mathrm{~min}$. The variables assessed were the total length walked, the duration of immobility, the time spent in level 1 and level 6, in the light stimulus area (square 1.1), in the area of the same level but opposite the light stimulus (square 1.6), in the area $25 \mathrm{~cm}$ above the source (square 6.1), in the area diagonal to the source (square 5.5) and in the entrance area (square 6.6). The amount of locomotor activity was assessed by time of immobility and the length of the path. These parameters are relevant to investigate potential effects of thymol on motor and arousal functions but a

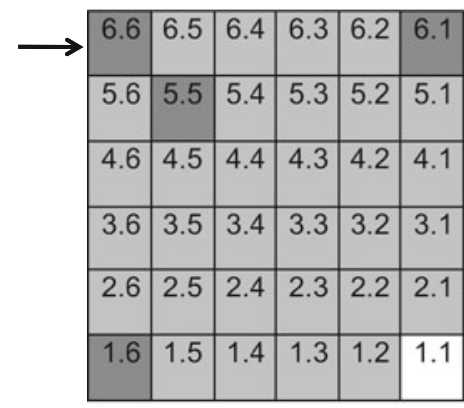

b
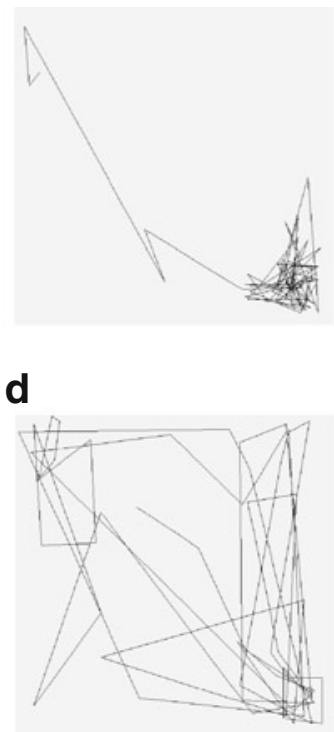

C

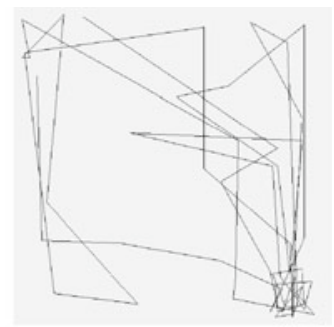

e

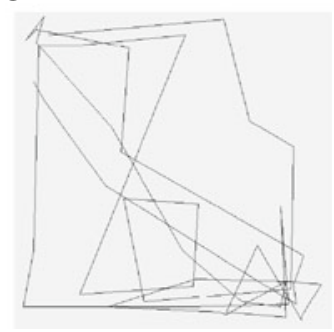

Figure 1. Examples of walking paths of an individual bee tested to the 200-lx stimuli. Bees were introduced in the experimental setup (a) used for phototaxis investigation at the top left corner (arrow) $1 \mathrm{~h}$ after treatment. The bee had received, on the thorax, $1 \mu \mathrm{l}$ of a $0.1 \%$ acetone solution (b) or a thymol solution containing $1 \mathrm{ng}$ (c), $10 \mathrm{ng}$ (d) or $100 \mathrm{ng}$ (e). Recording was performed $1 \mathrm{~h}$ after the thoracic application during $3 \mathrm{~min}$. Phototaxis was analysed by the measurement of the time spent in the light source area (square 1.1 in white), in the entrance area of the open field (square 6.6 in dark grey), in the area vertically above the source (square 6.1 in dark grey), in the area horizontal to the source (square 1.6 in dark grey) and in the area diagonal to the source (square 5.5 in dark grey). 
are not suited for investigations on phototaxis. The analysis of the spatial pattern, performed by the measurement of time spent in the squares, can reveal the phototaxic behaviour.

\subsection{Data analysis}

The same bee was tested only for a single light intensity. Data are presented as mean values \pm SEM. Differences among treated groups were assessed by analysis of variance (ANOVA) and Scheffe's post hoc tests. Differences were deemed statistically significant at $P<0.05$. Normality and equal variances of data used for ANOVA were confirmed.

\section{RESULTS}

\subsection{Bee mortality}

Mortality was measured for the 48-h period of observation after the beginning of the treatment. Mortality was not significantly different between groups $\left(\mathrm{Chi}^{2}=5.9, \mathrm{df}=3, P=\right.$ $0.115)$. In the present experimental conditions, the mean percentage of dead bees in each group was $44 \pm 27$ (control), $48 \pm 19$ ( $1 \mathrm{ng} / \mathrm{bee}), 62 \pm 27$ (10 ng/bee) and $44 \pm 26$ (100 ng/bee) after the topical application. ANOVA did not indicate a significant difference between groups $(F=$ $0.812, \mathrm{dl}=3, P=0.50)$. The mortality of bees treated with thymol was comparable from those of control bees within the 48-h period of observation.

\subsection{Amount of locomotor activity}

A first experiment was conducted with a 200-lx light intensity. When introduced in the vertical open-field, honeybees moved to level 1 and went to square 1.1. The bees first moved with positive gravitaxis from level 6 to level 1 then, they walked to square 1.1. This movement towards the 200-lx light source was a positive phototaxis (Figure 1b). The total length walked and the duration of immobility (Table I) were not significantly different across the treated groups when tested $1 \mathrm{~h}$ after treatment (ANOVA, total length: $F=$
2.205, $\mathrm{df}=3, P=0.09$; immobility duration: $F=$ $0.448, \mathrm{df}=3, P=0.720$ ). Once again, when bees were exposed to $400 \mathrm{~lx}$, there was no significant difference in the length walked $(F=1.178, \mathrm{df}=3$, $P=0.33)$ and the duration of immobility $(F=$ $0.789, \mathrm{df}=3, P=0.51)$. The total length $(F=$ $0.274, \mathrm{df}=3, P=0.84)$ and the duration of immobility $(F=0.625, \mathrm{df}=3, P=0.60)$ were not modified by treatment when bees were tested for a 600-lx light intensity (Table I).

By contrast, $24 \mathrm{~h}$ after treatment the distance covered by the bees differed between groups (ANOVA: $F=7.242$, $\mathrm{df}=3, P=0.0006$ ) when bees were tested for the 200-1x stimulus (Table I). A significant difference was revealed between control and $100 \mathrm{ng}$ groups, control and $10 \mathrm{ng}$ groups, $1 \mathrm{ng}$ and $100 \mathrm{ng}$ groups and $1 \mathrm{ng}$ and $10 \mathrm{ng}$ groups, $(P<0.05$ Scheffé pairwise post hoc tests). However, immobility duration was identical under this stimulus condition $(F=$ 1.207, $\mathrm{df}=3, P=0.32)$ and for the higher intensity of light (400 1x: $F=1.862, \mathrm{df}=3, P=$ 0.17 ; 600 lx: $F=0.442, \mathrm{df}=3, P=0.72$; Table I). These results indicated that in low (200 lx), medium (400 lx) and high (600 lx) intensity light conditions, thymol had no effect on locomotor activity $1 \mathrm{~h}$ after a topical application. However, $24 \mathrm{~h}$ after treatment 10 and $100 \mathrm{ng}$ thymol-treated bees were more active than control bees under the low-intensity stimulus (200 lx).

\subsection{Phototaxis}

With 200-lx illumination, the $1 \mathrm{~h}$ test indicated that the time spent in square 1.1 was significantly different between groups $(F=5.17, \mathrm{df}=3, P=$ 0.0029; Figures $1 \mathrm{~b}-\mathrm{e}$ and $2 \mathrm{a}$ ). Control bees were present in the square 1.1 for a longer period than bees that had received 10 or $100 \mathrm{ng}$ thymol $(P<$ 0.05 Scheffé pairwise post hoc tests). This time for the $24 \mathrm{~h}$ test (Figure 2b), a difference was found for level 6 between groups $(F=13.25, \mathrm{df}=$ $3, P=0.0001)$. Control and $1-n g /$ bee groups spent less time than the 100-ng/bee group in level $6(P<$ 0.05 Scheffé pairwise post hoc tests). A significant treatment effect was still observed for level 1 ( $F=$ 24.777, $\mathrm{df}=3, P=0.0001)$. Control bees were still 
Table I. Thymol effect on locomotion of bees.

\begin{tabular}{|c|c|c|c|c|c|}
\hline & & \multicolumn{2}{|c|}{ Immobility (s) } & \multicolumn{2}{|c|}{ Total length walked (cm) } \\
\hline & & $1 \mathrm{~h}$ & $24 \mathrm{~h}$ & $1 \mathrm{~h}$ & $24 \mathrm{~h}$ \\
\hline \multirow[t]{4}{*}{$200 \mathrm{~lx}$} & Control & $5 \pm 7 \mathrm{a}$ & $0.6 \pm 1 \mathrm{a}$ & $220 \pm 58 \mathrm{a}$ & $385 \pm 126 a$ \\
\hline & $1 \mathrm{ng} / \mathrm{bee}$ & $7.8 \pm 20 \mathrm{a}$ & $3.4 \pm 7 \mathrm{a}$ & $232 \pm 78 \mathrm{a}$ & $350 \pm 123 a$ \\
\hline & $10 \mathrm{ng} / \mathrm{bee}$ & $3.9 \pm 7.5 \mathrm{a}$ & $2.6 \pm 4.2 \mathrm{a}$ & $279 \pm 93 a$ & $516 \pm 62 b$ \\
\hline & $100 \mathrm{ng} / \mathrm{bee}$ & $3.6 \pm 4.4 \mathrm{a}$ & $1.2 \pm 1.6 \mathrm{a}$ & $228 \pm 71 \mathrm{a}$ & $519 \pm 75 b$ \\
\hline \multirow[t]{4}{*}{400 lx } & Control & $29 \pm 31 \mathrm{a}$ & $0.8 \pm 1.5 \mathrm{a}$ & $167 \pm 66 \mathrm{a}$ & $485 \pm 240 \mathrm{a}$ \\
\hline & $1 \mathrm{ng} / \mathrm{bee}$ & $29 \pm 31 \mathrm{a}$ & $8.6 \pm 9 \mathrm{a}$ & $178 \pm 69 \mathrm{a}$ & $342 \pm 175 a$ \\
\hline & $10 \mathrm{ng} / \mathrm{bee}$ & $58 \pm 55 \mathrm{a}$ & $28 \pm 41 \mathrm{a}$ & $113 \pm 70 \mathrm{a}$ & $398 \pm 172 a$ \\
\hline & $100 \mathrm{ng} / \mathrm{bee}$ & $42 \pm 50 \mathrm{a}$ & $1.8 \pm 2.7 \mathrm{a}$ & $168 \pm 87 \mathrm{a}$ & $585 \pm 208 \mathrm{a}$ \\
\hline \multirow[t]{4}{*}{$600 \mathrm{~lx}$} & Control & $18 \pm 25 \mathrm{a}$ & $6.8 \pm 10 \mathrm{a}$ & $204 \pm 97 \mathrm{a}$ & $390 \pm 200 a$ \\
\hline & $1 \mathrm{ng} / \mathrm{bee}$ & $18 \pm 19 a$ & $17 \pm 28 \mathrm{a}$ & $213 \pm 96 a$ & $411 \pm 237 \mathrm{a}$ \\
\hline & $10 \mathrm{ng} / \mathrm{bee}$ & $15 \pm 19 a$ & $8.3 \pm 18 \mathrm{a}$ & $232 \pm 114 a$ & $352 \pm 254 \mathrm{a}$ \\
\hline & $100 \mathrm{ng} / \mathrm{bee}$ & $29 \pm 35 a$ & $9.1 \pm 15 \mathrm{a}$ & $195 \pm 93 \mathrm{a}$ & $373 \pm 170 \mathrm{a}$ \\
\hline
\end{tabular}

Duration of immobility (s) and the total length $(\mathrm{cm})$ were recorded during the 3-min test. The same bee was tested for a single stimulus intensity (200, 400 or 600 lx), 1 and $24 \mathrm{~h}$ after treatment. Mean \pm SEM followed by different letters are significantly different at the $\alpha=0.05$ level (ANOVA followed by Scheffe's test)

more present in this level than bees of the 10 and $100 \mathrm{ng}$ groups $(P<0.05$ Scheffé pairwise post hoc tests). In addition, a significant difference between groups was still observed for square 1.1 ( $F=$ 24.831, $\mathrm{df}=3, P=0.0001)$. According to Scheffe's tests, control and $1 \mathrm{ng} /$ bee groups spent more time than 10 and $100 \mathrm{ng} /$ bee groups in square $1.1(P<$ 0.05 Scheffé pairwise post hoc tests).

When the behaviour of the bees was examined $1 \mathrm{~h}$ after treatment and with $400 \mathrm{~lx}$ (Figure 2c), a significant effect of treatment was still observed $(F=4.762, \mathrm{df}=3, P=0.008)$ in square 1.1 with less time spent in this square by the $100 \mathrm{ng} / \mathrm{bee}$ group in comparison to the control $(P<0.05$ Scheffé pairwise post hoc test). Twenty-four hours after the topical application (Figure 2d), between-group differences in time spent in square 1.1 did not reach a significant level (square 1.1: $F=1.062$, df=3, $P=0.39$ ).

Again, for the highest intensity of the stimuli (600 lx), ANOVA indicated that there was no difference between groups when tested $1 \mathrm{~h}$ after treatment (square 1.1: $F=1.225, \mathrm{df}=3, P=$ 0.3125 ; Figure 2e) and $24 \mathrm{~h}$ after treatment (square 1.1: $F=0.553, \mathrm{df}=3, P=0.65$; Figure 2f).

\section{DISCUSSION}

The search for alternatives to pesticides is related to the preservation of the environment and reducing the impact on non-target insects i.e. the honeybee. The present research aimed to investigate if thymol exposure could have a negative impact on the state of the colony.

Because an increase of bee longevity has been reported for thymol (Costa et al. 2010), we measured the mortality of bees all along the experiment. No significant difference was found between groups in the conditions used. The mortality level was not modified by thymol. However, half of the bees died $48 \mathrm{~h}$ after treatment. This relatively high mortality rate can be partly explained by the stress of the different manipulations of bees especially the cooling and the storing of bees individually in a syringe during resting periods.

Here, we analysed the effect of thymol on bee behaviour; we examined the locomotion of bees in laboratory conditions 1 and $24 \mathrm{~h}$ after a topical application. It has recently been shown in Phaenicia sericata that topically applied 
a

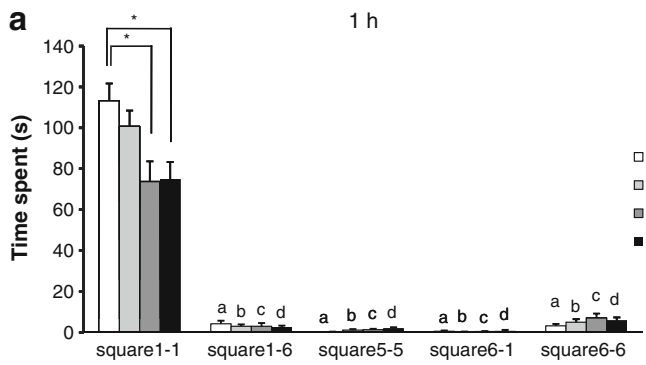

C
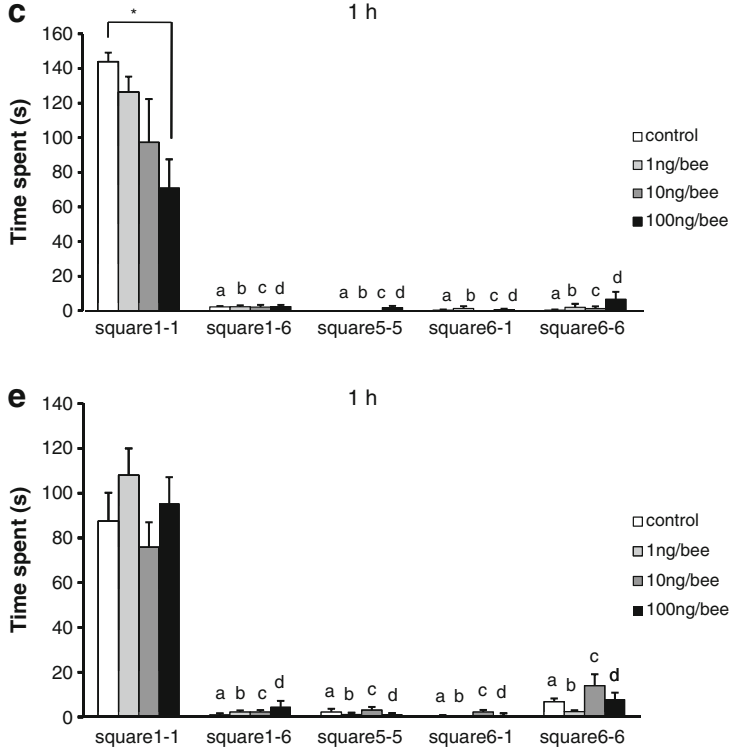

b
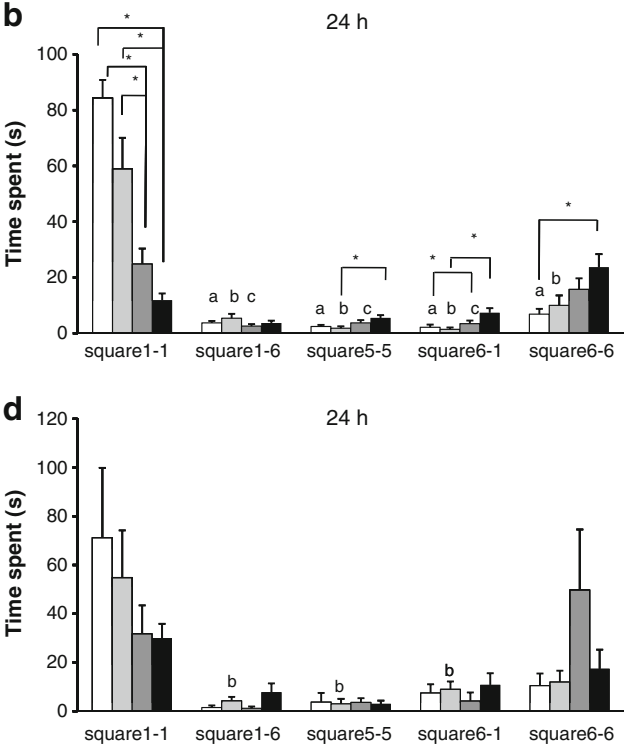

f

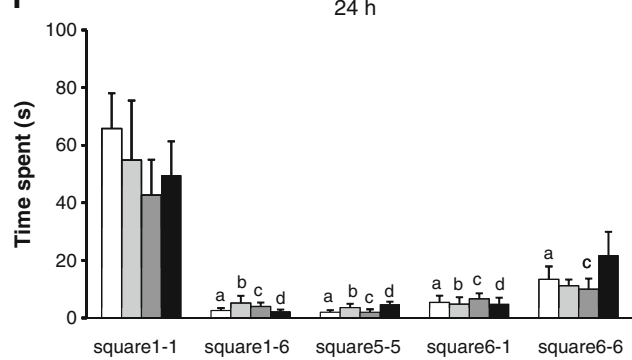

Figure 2. Effect of thymol on the phototaxic behaviour. Bees were tested for different light stimuli: 200 lx (a, b), $400 \mathrm{~lx}(\mathbf{c}, \mathbf{d})$ and $600 \mathrm{~lx}(\mathbf{e}, \mathbf{f})$. Tests were undertaken $1 \mathrm{~h}(\mathbf{a}, \mathbf{c}, \mathbf{e})$ and $24 \mathrm{~h}(\mathbf{b}, \mathbf{d}, \mathbf{e})$ after topical application of thymol $(1 \mu \mathrm{l})$. The time spent in the light source area (square 1-1), in the entrance area of the open field (square 6-6), in the area vertically above the source (square 6-1), in the area horizontal to the source (square 16 ) and in the area diagonal to the source (square 5-5) is indicated by mean \pm SEM from separate experiments performed in sextuplicates. Experiments were repeated three times with $200 \mathrm{~lx}$ and two times with 400 and $600 \mathrm{~lx}$. Statistically significant differences between treated groups are indicated by an asterisk (ANOVA and Scheffe's post hoc tests). The comparisons to square 1-1 were indicated by different letters for each treated group: $a$ for the control group, $b$ for the $1 \mathrm{ng} /$ bee group, $c$ for the $10 \mathrm{ng} /$ bee group and $d$ for the $100 \mathrm{ng} / \mathrm{bee}$ group (repeated measures ANOVA, and Scheffe's post hoc tests).

thymol $(50 \mu \mathrm{g})$ reduced dorsolongitudinal muscles activity and the wings were motionless (Waliwitiya et al. 2010). By contrast, our results indicated that $24 \mathrm{~h}$ after a topical application (100 ng/bee), bees were more active. This suggested firstly that in our case thymol had no effect on muscles. Secondly, bees may have been more active because the application of thymol promoted a general arousal similar to that caused by octopamine (Roeder 1999), perhaps suggesting that thymol had targeted octopamine receptors.

Here, effects of treatments were compared for walking parameters, in a device that was illuminated at its bottom right corner. At $1 \mathrm{ng} /$ bee, thymol had no significant effect on locomotion or phototaxis. However, bees exposed to 10 or $100 \mathrm{ng}$ were less attracted than control bees to light stimuli of low intensity. 
This strongly suggested that the visual function could be impaired by thymol. Indeed, in addition to $\mathrm{GABA}_{\mathrm{A}}$ channels (Priestley et al. 2003), thymol targets TRPL channels. TRP channels were first described in blind Drosophila mutants (Cosens and Manning 1969) and TRPL are of particular interest in phototransduction (Wang and Montell 2007). More recently, it was demonstrated in Drosophila that thymol inhibits TRPL channels (Parnas et al. 2009). Because thymol-based treatment was proposed for use at the end of summer, we investigated the effect of thymol from October to December, probably on winter bees. The long-lasting effects of thymol on summer bees need to be investigated. Indeed, foragers are known to be strongly positively phototactic (Menzel and Greggers 1985) in comparison to nurses (Ben-Shahar et al. 2003). Moreover, it was found that honeybee responses to treatment with a thymol formulation (Apiguard) change with age (Mondet et al. 2011). So additional data, taking into account the age of bees, seem necessary for investigations into the effect of thymol on the visual function of this insect. Moreover, because octopamine, tyramine and $\mathrm{GABA}_{\mathrm{A}}$ receptors are potential targets of thymol in the honeybee (Enan 2005; Priestley et al. 2003; Blenau et al. 2011), it is possible that thymol also affects behaviours that are relevant for division of labor, e.g. olfactory learning and sucrose perception. Indeed, it has been observed that phototactic behaviour correlates with gustatory responsiveness (Erber et al. 2006).

The work provides new insights into the biological and behavioural effects of thymol in the honeybee and will allow beekeepers to improve their technical expertise in the use of this molecule. Specific instructions to minimize exposure to bees should be provided.

\section{ACKNOWLEDGEMENTS}

We wish to thank Dr. M. Lambin, V. Britten from ADAM and B. Duquesnoy for technical assistance in the early stages of the experiments. P. Winterton's advice improved the English of the manuscript. The work was supported by the Conseil Régional MidiPyrénées, the Centre National de la Recherche Scientifique and the Centre Universitaire de Formation et de Recherche J.F. Champollion (Project 10051284).

\section{L'exposition au thymol réduit le comportement phototactique des abeilles (Apis mellifera) en condi- tions de laboratoire}

Thymol / abeille / phototactisme / essai en laboratoire

Thymolkontakt verringert das phototaktische Verhalten der Honigbiene (Apis mellifera) unter Laborbedingungen

Thymol / Honigbiene / Phototaxis / Labor / Bio-Assay

\section{REFERENCES}

Albo, G.N., Henning, C., Ringuelet, J., Reynaldi, F.J., De Giusti, M.R., Alippi, A.M. (2003) Evaluation of some essential oils for the control and prevention of American Foulbrood disease in honey bees. Apidologie 34, 417-427

Ben-Shahar, Y., Leung, H.T., Pak, W.L., Sokolowski, M.B., Robinson, G.E. (2003) cGMP-dependent changes in phototaxis: a possible role for the foraging gene in honey bee division of labor. J. Exp. Biol. 206, 2507-2515

Blenau, W., Rademacher, E., Baumann, A. (2011) Plant essential oils and formamidines as insecticides/ acaricides: what are the molecular targets? Apidologie. doi:10.1007/s13592-011-0108-7

Bloch, G., Meshi, A. (2007) Influences of octopamine and juvenile hormone on locomotor behavior and period gene expression in the honeybee, Apis mellifera. J. Comp. Physiol. A. Neuroethol. Sens. Neural. Behav. Physiol. 193, 181-199

Cosens, D.J., Manning, A. (1969) Abnormal electroretinogram from a Drosophila mutant. Nature 224, 285-287

Costa, C., Lodesani, M., Maistrello, L. (2010) Effect of thymol and resveratrol administered with candy or syrup on the development of Nosema ceranae and on the longevity of honeybees (Apis mellifera L.) in laboratory conditions. Apidologie 41, 141-150

Delgado, R., Bacigalupo, J. (2009) Unitary recordings of TRP and TRPL channels from isolated Drosophila retinal photoreceptor rhabdomeres: activation by light and lipids. J. Neurophysiol. 101, 2372-2379

Enan, E.E. (2005) Molecular and pharmacological analysis of an octopamine receptor from American cockroach and fruit fly in response to plant essential oils. Arch. Insect Biochem. Physiol. 59, 161-171 
Erber, J., Hoormann, J., Scheiner, R. (2006) Phototactic behaviour correlates with gustatory responsiveness in honey bees (Apis mellifera L.). Behav. Br. Res. 174, 174-180

Floris, I., Satta, A., Cabras, P., Garau, V.L., Angioni, A. (2004) Comparison between two thymol formulations in the control of Varroa destructor: effectiveness, persistence, and residues. J. Econ. Entomol. 97, 187-191

Imdorf, A., Kilchenmann, V., Bogdanov, S., Bachofen, B., Beretta, C. (1995) Toxic effects of thymol, camphor, menthol and eucalyptol on Varroa jacobsoni Oud and Apis mellifera L. in a laboratory test. Apidologie 26, 27-31

Lambin, M., Armengaud, C., Raymond, S., Gauthier, M. (2001) Imidacloprid-induced facilitation of the proboscis extension reflex habituation in the honeybee. Arch. Insect Biochem. Physiol. 48, 129-134

Landry, C.R., Castillo-Davis, C.I., Ogura, A., Liu, J.S., Hartl, D.L. (2007) Systems-level analysis and evolution of the phototransduction network in Drosophila. Proc. Natl. Acad. Sci. U S A. 104, 3283-3288

Menzel, R., Greggers, U. (1985) Natural phototaxis and its relationship to color-vision in honeybees. J. Comp. Physiol. 157, 311-321

Milani, N. (1999) The resistance of Varroa jacobsoni Oud. to acaricides. Apidologie 30, 229-234

Mondet, F., Goodwin, M., Mercer, A. (2011) Age-related changes in the behavioural response of honeybees to Apiguard ${ }^{\mathbb{R}}$, a thymol-based treatment used to control the mite Varroa destructor. J. Comp. Physiol. A. 197, 1055-1062

Nerio, L.S., Olivero-Verbel, J., Stashenko, E. (2010) Repellent activity of essential oils: a review. Bioresour. Technol. 101, 372-378

Pandey, S.K., Upadhyay, S., Tripathi, A.K. (2009) Insecticidal and repellent activities of thymol from the essential oil of Trachyspermum ammi (Linn) Sprague seeds against Anopheles stephensi. Parasitol. Res. 105, 507-512

Parnas, M., Peters, M., Dadon, D., Lev, S., Vertkin, I., Slutsky, I., Minke, B. (2009) Carvacrol is a novel inhibitor of Drosophila TRPL and mammalian TRPM7 channels. Cell Calcium. 45, 300-309

Pavela, R., Vrchotovà, N., Triska, J. (2009) Mosquitocidal activities of thyme oils (Thymus vulgaris L.) against Culex quinquefasciatus (Diptera: Culicidae). Parasitol. Res. 105, 1365-1370
Phillips, A.K., Appel, A.G., Sims, S.R. (2010) Topical toxicity of essential oils to the German cockroach (Dictyoptera: Blattellidae). J. Econ. Entomol. 103, 448-459

Priestley, C.M., Williamson, E.M., Wafford, K.A., Sattelle, D.B. (2003) Thymol, a constituent of thyme essential oil, is a positive allosteric modulator of human $\mathrm{GABA}(\mathrm{A})$ receptors and a homo-oligomeric GABA receptor from Drosophila melanogaster. Br. J. Pharmacol. 140, 1363-1372

Roeder, T. (1999) Octopamine in invertebrates. Prog. Neurobiol. 59, 533-561

Singh, V.K., Singh, S., Singh, D.K. (1999) Effect of active molluscicidal component of spices on different enzyme activities and biogenic amine levels in the nervous tissue of Lymnaea acuminata. Phytother. Res. 13, 649-654

Tabanca, N., Bernier, U.R., Tsikolia, M., Becnel, J.J., Sampson, B., Werle, C., Demirci, B., Bal̦er, K.H., Blythe, E.K., Pounders, C., Wedge, D.E. (2010) Eupatorium capillifolium essential oil: chemical composition, antifungal activity, and insecticidal activity. Nat. Prod. Commun. 5, 1409-1415

Thamm, M., Balfanz, S., Scheiner, R., Baumann, A., Blenau, W. (2010) Characterization of the 5-HT1A receptor of the honeybee (Apis mellifera) and involvement of serotonin in phototactic behavior. Cell. Mol. Life Sci. 67, 2467-2479

Umpierrez, M.L., Santos, E., Gonzalez, A., Rosini, C. (2011) Plant essential oils as potential control agents of varroatosis. Phytochem. Rev. 10, 227-244

Waliwitiya, R., Kennedy, C.J., Lowenberger, C.A. (2009) Larvicidal and oviposition-altering activity of monoterpenoids, trans-anithole and rosemary oil to the yellow fever mosquito Aedes aegypti (Diptera: Culicidae). Pest. Manag. Sci. 65, 241-248

Waliwitiya, R., Belton, P., Nicholson, R.A., Lowenberger, C.A. (2010) Effects of the essential oil constituent thymol and other neuroactive chemicals on flight motor activity and wing beat frequency in the blowfly Phaenicia sericata. Pest. Manag. Sci. 66, 277-289

Wang, T., Montell, C. (2007) Phototransduction and retinal degeneration in Drosophila. Pflugers. Arch. 454, 821-847

Wijnen, H., Naef, F., Boothroyd, C., Claridge-Chang, A., Young, M.W. (2006) Control of daily transcript oscillations in Drosophila by light and the circadian clock. PLOS Gen. 2, 326-343 